\title{
Is primary aldosteronism a potential risk factor for aortic dissection? A case report and literature review
}

\author{
Ying Zhang, Fang Luo* ${ }^{*}$, Peng Fan, Xu Meng, Kunqi Yang and Xianliang Zhou
}

\begin{abstract}
Background: Primary aldosteronism (PA) increases the risk of cardiovascular morbidity, including stroke, coronary artery disease, atrial fibrillation, and heart failure. The relationship between primary aldosteronism and aortic dissection has rarely been reported. We report a case of aortic dissection caused by secondary hypertension from PA and review similar cases in the literature.

Case presentation: A 56-year-old woman with a history of surgery for aortic dissection presented for follow-up of hypertension and a left adrenal mass. She had been diagnosed with hypertension and hypokalemia in 2003. Blood pressure had been controlled by antihypertensive medications. In 2009, she presented with chest and back pain; she was diagnosed with aortic dissection by computed tomography (CT). She underwent placement of an endovascular aortic stent graft. CT at that time showed a left adrenal mass with a diameter of $1 \mathrm{~cm}$. In 2017, CT reexamination revealed that the left adrenal mass had grown to $3 \mathrm{~cm}$ in diameter. Laboratory data showed blood potassium $2.4 \mathrm{mmol} / \mathrm{L}$ (reference range: $3.5-5.3 \mathrm{mmol} / \mathrm{L}$ ). The plasma aldosterone/renin ratio was elevated because of suppressed plasma renin and elevated serum aldosterone levels. Plasma aldosterone levels were not suppressed after taking captopril. Positron emission tomography/CT showed that the left adrenal tumor radiographic uptake was slightly increased (maximum standardized uptake value of 2.2), and metastasis was not detected. Laparoscopic adrenalectomy was performed, and an adrenocortical adenoma was confirmed histopathologically. After surgery, blood pressure and laboratory findings were within their reference ranges without any pharmacological treatment.

Conclusions: Our patient and the literature suggest that PA is a potential cause of aortic dissection. Diagnosing PA in the early stages of the disease and early treatment are important because affected patients may be at increased risk of aortic dissection.
\end{abstract}

Keywords: Aortic dissection, Case report, Hypertension, Primary aldosteronism

\section{Background}

Primary aldosteronism (PA) is a group of disorders in which aldosterone production is inappropriately high [1]. Once thought to be rare, PA is now reported to be the most common cause of secondary hypertension, with a prevalence of 5 to $10 \%$ among

\footnotetext{
* Correspondence: luofang@fuwaihospital.org

Department of Cardiology, Fuwai Hospital, National Center for Cardiovascular Diseases, Chinese Academy of Medical Sciences and Peking Union Medical College, No. 167, Beilishi Road, Beijing 100037, China
}

patients with hypertension and up to 17 to $23 \%$ among patients with resistant hypertension [2, 3]. PA is commonly caused by an adrenal adenoma, unilateral or bilateral adrenal hyperplasia, or (rarely) adrenal carcinoma or inherited familial hyperaldosteronism [2]. Compared with primary hypertension, PA causes more end-organ damage and is associated with excess cardiovascular morbidity, including heart failure, stroke, myocardial infarction, and atrial fibrillation $[4,5]$. PA also increases the risk of diabetes,

(c) The Author(s). 2020 Open Access This article is licensed under a Creative Commons Attribution 4.0 International License, which permits use, sharing, adaptation, distribution and reproduction in any medium or format, as long as you give appropriate credit to the original author(s) and the source, provide a link to the Creative Commons licence, and indicate if changes were made. The images or other third party material in this article are included in the article's Creative Commons licence, unless indicated otherwise in a credit line to the material. If material is not included in the article's Creative Commons licence and your intended use is not permitted by statutory regulation or exceeds the permitted use, you will need to obtain permission directly from the copyright holder. To view a copy of this licence, visit http://creativecommons.org/licenses/by/4.0/ The Creative Commons Public Domain Dedication waiver (http://creativecommons.org/publicdomain/zero/1.0/) applies to the data made available in this article, unless otherwise stated in a credit line to the data. 
metabolic syndrome, arterial wall stiffness, and left ventricular hypertrophy $[4,6,7]$. The cardiovascular system is affected even in normotensive individuals with early and mild PA [8]. Death resulting from cardiovascular causes is more common among patients with PA compared with matched control patients with primary hypertension [9]. Targeting PA treatment is effective in controlling blood pressure, protecting target organs, and improving cardiovascular outcomes [10].

Animal studies have demonstrated that aldosterone has a destructive effect on the aorta [11]. Recent clinical studies have also revealed that the diameter of the aorta in patients with PA is larger than that in patients with essential hypertension [12]. However, there are few studies on the relationship between PA and aortic dissection (AD), partly because of the low incidence of AD (35 cases per 100,000 people per year) and underdiagnosis of PA (screening rate: one case per 550 people) [13]. We report a new case of $\mathrm{AD}$ associated with secondary hypertension because of primary aldosteronism. In addition, similar cases in the literature are briefly summarized and discussed.

\section{Case presentation}

A 56-year-old woman presented to our hospital with a history of a left adrenal mass and high blood pressure. She had been diagnosed with hypertension in 2003. Her blood pressure was controlled with amlodipine and was less than $140 / 90 \mathrm{mmHg}$ at a dose of $5 \mathrm{mg}$ daily. She reported frequent fatigue. She was admitted to the hospital, diagnosed with hypokalemia and treated with potassium supplements. In 2009, she presented with chest pain and back pain. A computed tomography $(\mathrm{CT})$ angiogram demonstrated dissection of the descending aorta (Fig. 1a). Thoracic endovascular aortic repair (TEVAR) with a stent graft was successful. At the same time, she was found to have a left adrenal mass approximately $1 \mathrm{~cm}$ in diameter. She was started on valsartan to reduce blood pressure. Her blood pressure was $130-140 / 90-100 \mathrm{mmHg}$ initially but gradually became difficult to control. Despite treatment with three antihypertensive drugs, her blood pressure still reached
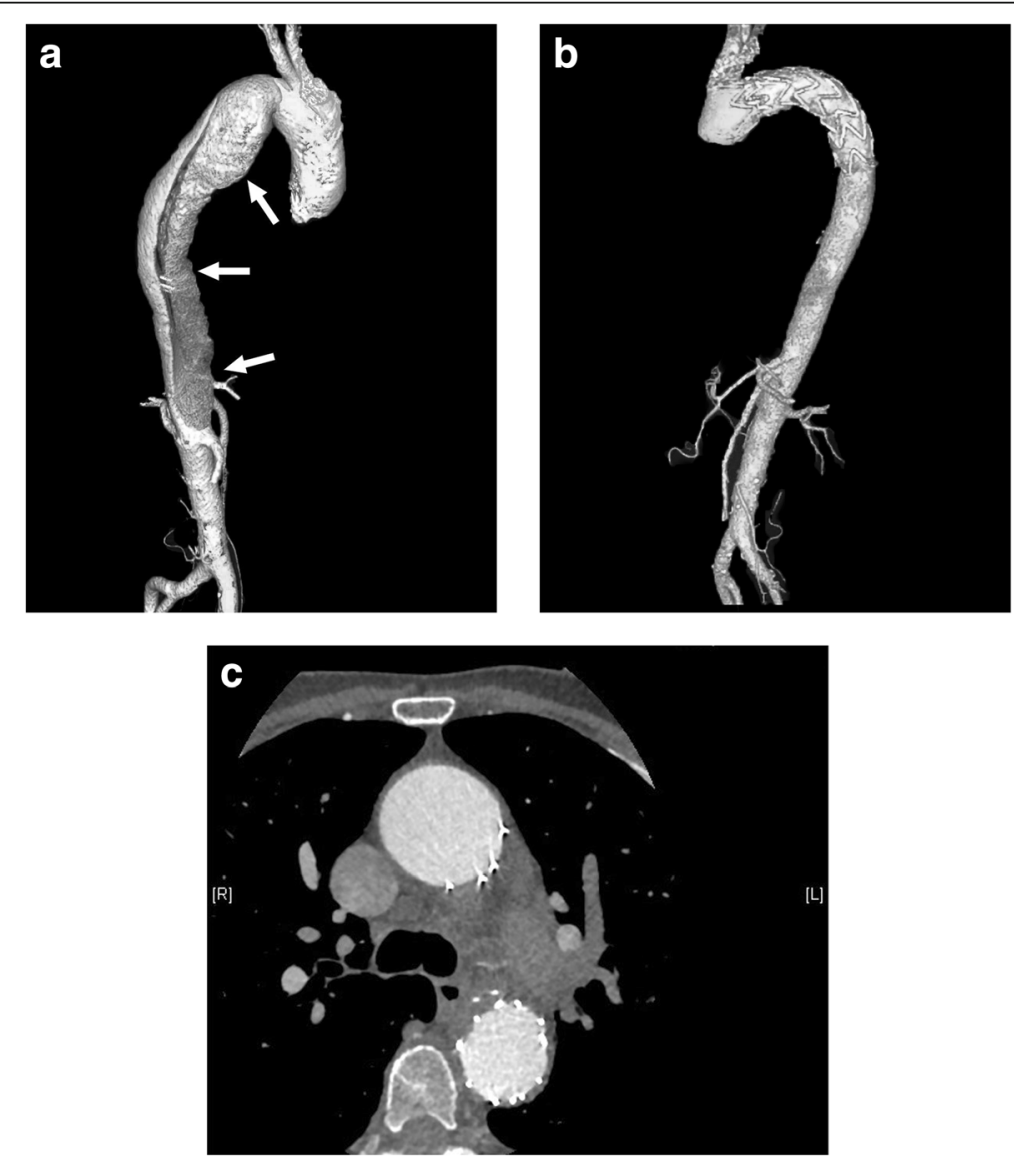

Fig. 1 CT angiograms. a Dissection of the descending aorta in 2009 (arrows). b, c Repeat study in 2017 revealed no new dissection after TEVAR. CT: computed tomography; TEVAR: thoracic endovascular aortic repair 
180/110 mmHg. In 2017, repeat aortic CT revealed no new dissection (Fig. 1b, c). CT of the abdomen showed that the left adrenal mass had grown to more than $3 \mathrm{~cm}$ in diameter (Fig. 2).

She was investigated further in our hospital. Monitoring of 24-h ambulatory blood pressure demonstrated an average blood pressure of $182 / 102 \mathrm{mmHg}$. Laboratory data showed blood potassium $2.4 \mathrm{mmol} / \mathrm{L} \quad(3.5-5.3$ $\mathrm{mmol} / \mathrm{L}$ ). The circadian rhythm of cortisol, overnight 1 mg dexamethasone suppression test, sex hormone levels, as well as catecholamines and metabolites were normal (Table 1). Abdominal CT showed no abnormality in the kidney and renal arteries. The diagnosis of primary hyperaldosteronism was confirmed by a captopril challenge test (Table 2). Plasma aldosterone/renin ratio was elevated due to a suppressed plasma renin and elevated serum aldosterone level. Plasma aldosterone levels were not suppressed after taking captopril. Positron emission tomography (PET)/CT showed that the left adrenal tumor radiographic uptake was slightly increased, with a maximum standardized uptake value (SUVmax) of 2.2, and no metastases were detected.

After discussing the medical and surgical management options, the patient decided to initially opt for medical management. She took spironolactone and two other antihypertensive drugs. Five days later, the patient's blood pressure fell to $142 / 85 \mathrm{mmHg}$, and potassium had risen to 3.93 $\mathrm{mmol} / \mathrm{L}$. Despite initial good control of hypertension, blood pressures rose again and after $8 \mathrm{~m}$ of medical treatment, the patient elected to undergo left laparoscopic adrenalectomy. The tumor, which was about $3 \mathrm{~cm}$ in diameter, was in the middle of the adrenal gland (Fig. 3). Adrenocortical adenoma was confirmed histopathologically.

The postoperative course was uneventful, and the patient's blood pressure and serum potassium remained normal without medication.

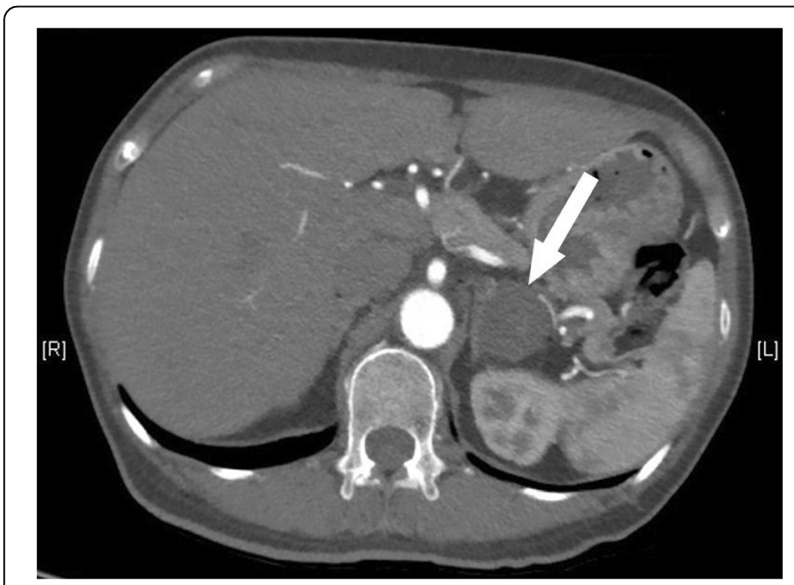

Fig. 2 Abdominal CT. Left adrenal mass in 2017 (arrows). CT: computed tomography

\section{Discussion and conclusions}

In this article, we present an incidental finding of $\mathrm{AD}$ in a patient with PA. The patient was known to have hypertension and hypokalemia for many years but was not screened for PA during this time. Although the hypertension was controlled (less than $140 / 90 \mathrm{mmHg}$ ) by taking antihypertensive drugs, dissection still occurred. We consider that PA is a risk factor for AD independent of hypertension. Because of the high mortality and poor prognosis of $\mathrm{AD}$, the association of $\mathrm{PA}$ with $\mathrm{AD}$ deserves greater attention.

An electronic literature search in PubMed was performed to identify case reports relating to PA with AD. Search words included "primary hyperaldosteronism" and "aortic dissection". All references of included reports and relevant reviews were screened manually for additional potential eligible cases. The results were limited to full-text articles published in English. Seven available reports were included in the review [14-20] (Table 3). The PA features of these patients are summarized as follows: In the PA subtype classification, five patients had adrenal adenoma, one patient had nodular cortical hyperplasia, and one patient had glucocorticoidremediable aldosteronism. In patients with adrenal adenoma, the diameter of the nodule ranged from 1.0 to 3.0 $\mathrm{cm}$, and the majority were left-sided (six out of seven, 85.7\%). AD commonly occurs in the sixth and seventh decades of life [21]. However, in the patients with PA, the mean age of onset of $\mathrm{AD}$ was $37.8 \pm 12.0$ years (range: $10-48$ years). The relatively young age suggests that the aldosterone hypersecretion possibly contributed to $\mathrm{AD}$. In these cases, PA patients with $\mathrm{AD}$ often had a delay in diagnosis and treatment. Two patients were diagnosed with PA following $\mathrm{AD}$, and three were diagnosed with PA with AD simultaneously. Only three patients had PA diagnosed before $\mathrm{AD}$, and in all the treatment of PA was inadequate. According to epidemiological studies, normokalemic hypertension constitutes the most common presentation of PA, with only a minority of patients with PA (9-37\%) being hypokalemic and hypokalemia probably occurring in only the more severe cases [2]. In our summary case reports, all cases in which plasma or serum potassium values were available had hypokalemia. It therefore appears likely that patients with $\mathrm{AD}$ tend to have more severe forms of PA. The above evidence raises the possibility that the damage of aldosterone to blood vessels and leading to $A D$ may be independent of blood pressure; furthermore, excessive aldosterone may be a risk factor for AD.

The actions of aldosterone in the vasculature have been studied over the last few years, and the mechanisms are beginning to be clarified. Animal studies show the importance of aldosterone in promoting vascular inflammation, resulting in endothelial dysfunction [22- 
Table 1 Laboratory findings on admission

\begin{tabular}{lll}
\hline Parameters & Values & Reference ranges \\
\hline Serum potassium $(\mathrm{mmol} / \mathrm{L})$ & 2.4 & $3.5-5.3$ \\
Creatinine $(\mathrm{umol} / \mathrm{L})$ & 98.7 & $44.0-133.0$ \\
Testosterone $(\mathrm{ng} / \mathrm{dL})$ & 11.69 & $14-76$ \\
Progesterone $(\mathrm{ng} / \mathrm{mL})$ & 0.08 & $<0.73$ \\
Estradiol $(\mathrm{pg} / \mathrm{mL})$ & 20.3 & $<32.2$ \\
Prolactin $(\mathrm{ng} / \mathrm{mL})$ & 4.73 & $1.8-20.3$ \\
Luteotropic hormone $(\mathrm{mlU} / \mathrm{mL})$ & 33.41 & $15.9-54.6$ \\
Follicle-stimulating hormone $(\mathrm{ulU} / \mathrm{mL})$ & 62.37 & $23.0-116.3$ \\
Plasma norepinephrine $(\mathrm{ng} / \mathrm{mL})$ & 0.43 & $0.104-0.548$ \\
Plasma epinephrine $(\mathrm{ng} / \mathrm{mL})$ & 0.005 & $0.02-0.08$ \\
Plasma dopamine $(\mathrm{ng} / \mathrm{mL})$ & 0.005 & $<0.03$ \\
Urinary Normetanephrine $(\mu \mathrm{g} / 24 \mathrm{~h})$ & 394 & $<1464$ \\
Urinary Metanephrine $(\mu \mathrm{g} / 24 \mathrm{~h})$ & 71 & $<394$ \\
Plasma total cortisol $(\mu \mathrm{g} / \mathrm{dL}) 8 \mathrm{am}-16 \mathrm{pm}-0$ am & $14.5-7.8-7.2$ & $4.3-22.4(7-9 \mathrm{am}) 3.1-16.7$ (3-5 pm) \\
ACTH (pg/mL) 8 am-16 pm-0 am & $9.7-<5-<5$ & $<46$ \\
1 mg DST (ug/dL) 8 am basal day-8 am post DST & $7.6-5.8$ & \\
\hline
\end{tabular}

ACTH adrenocorticotropic hormone, DST dexamethasone suppression test

24]. In addition, aldosterone recruitment of vascular inflammatory cells leads to the development of atherosclerosis [25]. Inflammation also increases the density of fibronectin and collagen in the media of arteries, resulting in arterial stiffness [26]. Aldosterone leads to medial smooth muscle cell proliferation and vascular remodeling, which is enhanced by endothelial injury [27]. The increase in the fibronectin/elastin ratio reflects alterations in extracellular matrix content [22], leading to increased medial thickness and media-to-lumen ratio, which is detected not only in rat aortas but also in the resistance arteries of patients with PA [26, 28, 29].

Aldosterone exerts its effect on blood vessels by activating the mineralocorticoid receptor (MR) within the vascular endothelium and vascular smooth muscle. Rickard et al. [30] demonstrated that endothelial function was impaired by the presence of MR in endothelial cells in a mouse model, indicating that endothelial MR played an important role in aldosterone-induced endothelial

Table 2 Results of the ARR tests, posture stimulation test and captopril challenge test

\begin{tabular}{llll}
\hline & PAC $(\mathrm{ng} / \mathrm{dL})$ & $\mathrm{DRC}(\mathrm{mU} / \mathrm{L})$ & ARR $(\mathrm{ng} / \mathrm{dl}: \mathrm{mU} / \mathrm{L})$ \\
\hline Supine position & 150.0 & 0.9 & 166.7 \\
Upright position & 175.0 & 2.9 & 60.3 \\
$\begin{array}{l}\text { Before captopril } \\
\text { challenge }\end{array}$ & 61.1 & 1.8 & 33.9 \\
$\begin{array}{l}\text { After captopril challenge } \\
\text { PAC }\end{array}$ & 60.4 & 5.4 & 11.2 \\
\hline
\end{tabular}

$P A C$ plasma aldosterone concentration, $D R C$ direct renin concentration, $A R R$ aldosterone-to-renin ratio dysfunction. In another study, a wire-induced carotid injury model using wild-type mice and mice with an inducible smooth muscle cell (SMC)-specific deletion of the MR. The results show that SMC-MR is necessary for aldosterone-induced vascular remodeling independent of effects on blood pressure. SMC-MR contributes to the induction of SMC vascular endothelial growth factor receptor 1 in the area of vascular injury and contributes to aldosterone-enhanced vascular placental growth factor expression [31].

MR antagonists, such as spironolactone and eplerenone, have a beneficial effect through inhibition of the vascular MR [11]. Spironolactone improves the structure and increases tone in the cerebral vasculature of

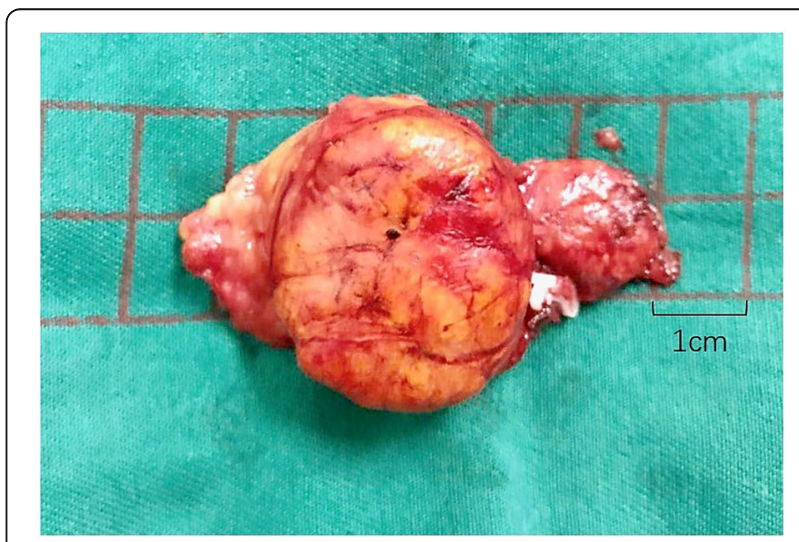

Fig. 3 Left adrenal gland after laparoscopic adrenalectomy in 2017. The solid nodule had a diameter of $3 \mathrm{~cm}$ and was confirmed histopathologically to be an adrenocortical adenoma 
Table 3 The summary of the reported cases of aortic dissection in patients with primary aldosteronism

\begin{tabular}{|c|c|c|c|c|c|c|c|c|c|c|c|}
\hline \multirow[t]{2}{*}{ Case } & \multirow[t]{2}{*}{ Study } & \multirow[t]{2}{*}{$\begin{array}{l}\text { Age/ } \\
\text { Sex }\end{array}$} & \multicolumn{3}{|c|}{$\begin{array}{l}\text { Age of } \\
\text { diagnostic }\end{array}$} & \multirow{2}{*}{$\begin{array}{l}\text { Serum } \\
\text { potassium } \\
(\mathrm{mmol} / \mathrm{l})\end{array}$} & \multirow{2}{*}{$\begin{array}{l}\text { AD } \\
\text { type } \\
\text { (D/S) }\end{array}$} & \multicolumn{3}{|l|}{ PA } & \multirow[t]{2}{*}{ PA Treatment before AD } \\
\hline & & & HTN & PA & $A D$ & & & Type & Side & $\begin{array}{l}\text { Size } \\
(\mathrm{cm})\end{array}$ & \\
\hline 1 & $\begin{array}{l}\text { Shimizu et al., } \\
1983 \text { [13] }\end{array}$ & $37 / F$ & 30 & 34 & 37 & 2.7 & $\mathrm{I} / \mathrm{A}$ & Adrenal adenoma & Right & 1.5 & Yes, spironolactone for 1 year \\
\hline 2 & $\begin{array}{l}\text { Lam et al., } 1999 \\
\text { [14] }\end{array}$ & $39 / \mathrm{M}$ & 39 & 39 & 43 & 2.7 & $\mathrm{I} / \mathrm{A}$ & Nodular cortical hyperplasia & Left & 1.4 & No \\
\hline 3 & $\begin{array}{l}\text { Safi et al., } 1999 \\
\text { [15] }\end{array}$ & $39 / F$ & 15 & 39 & 39 & $2.5-3.0$ & $\| / A$ & Adrenal adenoma & Left & 1 & No \\
\hline 4 & $\begin{array}{l}\text { Ahmed et al., } \\
2007 \text { [16] }\end{array}$ & $48 / \mathrm{M}$ & - & 48 & 48 & 3.2 & $\| / 1 / B$ & - & Left & 2 & $\begin{array}{l}\text { Yes, aldosterone antagonist } \\
\text { for } 1 \text { month }\end{array}$ \\
\hline 5 & $\begin{array}{l}\text { Harvey et al., } 2010 \\
{[17]}\end{array}$ & $39 / M$ & 29 & 39 & 39 & 2.5 & $\| I / / B$ & Adrenal adenoma & Left & - & $\begin{array}{l}\text { Yes, aldosterone antagonist } \\
\text { for } 6 \text { months }\end{array}$ \\
\hline 6 & $\begin{array}{l}\text { Hirai et al., } 2010 \\
\text { [18] }\end{array}$ & $38 / \mathrm{M}$ & - & 38 & 38 & 1.9 & III/B & Adrenal adenoma & Left & 1 & No \\
\hline 7 & $\begin{array}{l}\text { Shahrrava et al., } \\
2016 \text { [19] }\end{array}$ & $24 / \mathrm{M}$ & 10 & 18 & 10 & - & - & $\begin{array}{l}\text { Glucocorticoid remediable } \\
\text { aldosteronism }\end{array}$ & - & - & No \\
\hline 8 & Our case & $56 / F$ & 42 & 56 & 48 & 2.4 & $\| / \mathrm{B}$ & Adrenal adenoma & Left & 3 & No \\
\hline
\end{tabular}

HTN hypertension, PA primary aldosteronism, $A D$ aortic dissection, $D / S$ Debakey/Stanford

spontaneously hypertensive stroke-prone rats [32]. In addition, spironolactone increases the middle cerebral artery lumen diameter and reduces the wall/lumen ratio in spontaneously hypertensive stroke-prone rats compared [33]. MR antagonists also act on the aldosterone/ MR pathway in promoting vascular changes involved in atherogenesis. Eplerenone improves endothelial function and reduces superoxide generation in diet-induced atherosclerosis [34]. Eplerenone also decreases lesion size in early atherosclerosis in apolipoprotein E-deficient mice; targeting aldosterone by blocking its receptor has antiatherosclerotic effects [35].

Our case and data from the literature indicate that PA is a possible risk factor for AD independent of hypertension. This case underlines the importance of early detection of PA in the prevention of severe cardiovascular complications such as $\mathrm{AD}$, especially in high-risk groups of hypertensive patients and those with hypokalemia. Furthermore, the possible association between $\mathrm{AD}$ and PA should be elucidated in future studies.

\section{Abbreviations}

ACTH: Adrenocorticotropic hormone; AD: Aortic dissection; ARR: Aldosteroneto-renin ratio; CT: Computed tomography; DST: Dexamethasone suppression test; DRC: Direct renin concentration; D/S: Debakey/Stanford;

HTN: Hypertension; MR: Mineralocorticoid receptor; PA: Primary aldosteronism; PAC: Plasma aldosterone concentration; PET: Positron emission tomography; SMC: Smooth muscle cell; SUVmax: Maximum standardized uptake value; TEVAR: Thoracic endovascular aortic repair

\section{Acknowledgments}

We thank the patient for her participation in this study.

\section{Authors' contributions}

$F L, X M$, and $X L Z$ diagnosed and treated the patient. $Y Z$ and $F L$ reviewed the literature and drafted the manuscript. PF and KQY followed up with the patient. XLZ critically revised the manuscript. All the authors read and approved the final manuscript.

\section{Funding}

This research was supported by Beijing Nova Program (Z171100001117026) for editing the English text of a draft of this manuscript and article publication charges.

\section{Availability of data and materials}

All data generated or analyzed during this study are included in this published article.

Ethics approval and consent to participate

Not applicable.

\section{Consent for publication}

Written informed consent was obtained from the patient for publication of this case report and any accompanying images.

\section{Competing interests}

The authors declare that they have no competing interests.

Received: 27 February 2020 Accepted: 22 July 2020

Published online: 31 July 2020

\section{References}

1. Byrd JB, Turcu AF, Auchus RJ. Primary aldosteronism. Circulation. 2018; 138(8):823-35

2. Funder JW, Carey RM, Mantero F, Murad MH, Reincke M, Shibata H, et al. The management of primary aldosteronism: case detection, diagnosis, and treatment: an endocrine society clinical practice guideline. J Clin Endocrinol Metab. 2016;101(5):1889-916.

3. Douma S, Petidis K, Doumas M, Papaefthimiou P, Triantafyllou A, Kartali N, et al. Prevalence of primary hyperaldosteronism in resistant hypertension: a retrospective observational study. Lancet. 2008;371(9628):1921-6.

4. Monticone S, D'Ascenzo F, Moretti C, Williams TA, Veglio F, Gaita F, et al. Cardiovascular events and target organ damage in primary aldosteronism compared with essential hypertension: a systematic review and metaanalysis. Lancet Diabetes Endocrinol. 2018;6(1):41-50.

5. Monticone S, Burrello J, Tizzani D, Bertello C, Viola A, Buffolo F, et al. Prevalence and clinical manifestations of primary aldosteronism encountered in primary care practice. J Am Coll Cardiol. 2017:69(14):181120 
6. Hung C-S, Sung S-H, Liao C-W, Pan C-T, Chang C-C, Chen Z-W, et al. Aldosterone induces vascular damage. Hypertension. 2019;74(3):623-9.

7. Luther JM. Aldosterone in vascular and metabolic dysfunction. Curr Opin Nephrol Hypertens. 2016;25(1):16-21.

8. Mosso L, Carvajal C, González A, Barraza A, Avila F, Montero J, et al. Primary aldosteronism and hypertensive disease. Hypertension. 2003:42(2):161-5.

9. Reincke M, Fischer E, Gerum S, Merkle K, Schulz S, Pallauf A, et al. Observational study mortality in treated primary aldosteronism: the german conn's registry. Hypertension. 2012;60(3):618-24.

10. Rossi GP. Primary aldosteronism: Jacc state-of-the-art review. J Am Coll Cardiol. 2019;74(22):2799-811.

11. Yan Y, Wang C, Lu Y, Gong H, Wu Z, Ma X, et al. Mineralocorticoid receptor antagonism protects the aorta from vascular smooth muscle cell proliferation and collagen deposition in a rat model of adrenal aldosteroneproducing adenoma. J Physiol Biochem. 2018;74(1):17-24.

12. Zavatta G, Di Dalmazi G, Pizzi C, Bracchetti G, Mosconi C, Balacchi C, et al. Larger ascending aorta in primary aldosteronism: a 3-year prospective evaluation of adrenalectomy vs. Med Treatment Endocrine. 2019;63(3):4705.

13. Nienaber CA, Clough RE, Sakalihasan N, Suzuki T, Gibbs R, Mussa F, et al. Aortic dissection. Nat Rev Dis Primers. 2016;2:16053.

14. Shimizu A, Aoi W, Akahoshi M, Utsunomiya T, Doi Y, Suzuki S, et al. Elevation of plasma renin activity during pregnancy and rupture of a dissecting aortic aneurysm in a patient with primary aldosteronism. Jpn Heart J. 1983:24(6):995-1006

15. Lam K-Y, Lo C-Y. The clinicopathologic significance of unilateral adrenal cortical hyperplasia: report of an unusual case and a review of the literature. Endocr Pathol. 1999:10(3):243-9.

16. Safi AM, Kwan T, Afflu E, Alam M, Anderson JE, Clark LT. Coronary artery aneurysms, aortic dissection, and hypertension secondary to primary aldosteronism: a rare triad. A case report. Angiology. 1999;50(6):503-8.

17. Ahmed SH, Husain NM, Khawaja SN, Massey CV, Pettyjohn FS. Is primary hyperaldosteronism a risk factor for aortic dissection? Cardiology. 2007; 108(1):48-50.

18. Harvey KL, Riga C, Oconnor M, Hamady M, Chapman N, Gibbs RGJ. A rare case of aortic dissection and primary hyperaldosteronism. Ejves Extra. 2010; 20(3):546.

19. Hirai H, Shibata $T$, Sasaki $Y$, Fujii H, Kubo S, Suehiro S. Simultaneous surgery for chronic aortic dissection and adrenal adenoma with primary aldosteronism. Gen Thorac Cardiovasc Surg. 2010;58(5):235-8.

20. Shahrrava A, Moinuddin S, Boddu P, Shah R. A case of glucocorticoid remediable aldosteronism and thoracoabdominal aneurysms. Case Rep Endocrinol 2016, 2016:2017571.

21. Bossone E, LaBounty TM, Eagle KA. Acute aortic syndromes: Diagnosis and management, an update. Eur Heart J. 2018;39(9):739-49d.

22. Leibovitz E, Ebrahimian T, Paradis P, Schiffrin EL. Aldosterone induces arterial stiffness in absence of oxidative stress and endothelial dysfunction. J Hypertens. 2009;27(11):2192-200.

23. Kasal DA, Barhoumi T, Li MW, Yamamoto N, Zdanovich E, Rehman A, et al. T regulatory lymphocytes prevent aldosterone-induced vascular injury. Hypertension. 2012;59(2):324-30.

24. Bruder-Nascimento T, Ferreira NS, Zanotto CZ, Ramalho F, Pequeno IO, Olivon VC, et al. Nlrp3 inflammasome mediates aldosterone-induced vascular damage. Circulation. 2016;134(23):1866-80.

25. Moss ME, Jaffe IZ. Mineralocorticoid receptors in the pathophysiology of vascular inflammation and atherosclerosis. Front Endocrinol. 2015;6: 153.

26. Pu Q, Neves MF, Virdis A, Touyz RM, Schiffrin EL. Endothelin antagonism on aldosterone-induced oxidative stress and vascular remodeling. Hypertension. 2003;42(1):49-55.

27. Chrissobolis S. Vascular consequences of aldosterone excess and mineralocorticoid receptor antagonism. Curr Hypertens Rev. 2017;13(1):4656.

28. Virdis A, Neves MF, Amiri F, Viel E, Touyz RM, Schiffrin EL. Spironolactone improves angiotensin-induced vascular changes and oxidative stress. Hypertension. 2002;40(4):504-10.

29. Park JB, Schiffrin EL. Et(a) receptor antagonist prevents blood pressure elevation and vascular remodeling in aldosterone-infused rats. Hypertension. 2001;37(6):1444-9.

30. Rickard AJ, Morgan J, Chrissobolis S, Miller AA, Sobey CG, Young MJ. Endothelial cell mineralocorticoid receptors regulate deoxycorticosterone/ salt-mediated cardiac remodeling and vascular reactivity but not blood pressure. Hypertension. 2014;63(5):1033-40.

31. Pruthi D, McCurley A, Aronovitz M, Galayda C, Karumanchi SA, Jaffe IZ. Aldosterone promotes vascular remodeling by direct effects on smooth muscle cell mineralocorticoid receptors. Arterioscler Thromb Vasc Biol. 2014; 34(2):355-64.

32. Rigsby CS, Pollock DM, Dorrance AM. Spironolactone improves structure and increases tone in the cerebral vasculature of male spontaneously hypertensive stroke-prone rats. Microvasc Res. 2007;73(3):198-205.

33. Rigsby CS, Ergul A, Portik Dobos V, Pollock DM, Dorrance AM. Effects of spironolactone on cerebral vessel structure in rats with sustained hypertension. Am J Hypertens. 2011;24(6):708-15.

34. Rajagopalan S, Duquaine D, King S, Pitt B, Patel P. Mineralocorticoid receptor antagonism in experimental atherosclerosis. Circulation. 2002; 105(18):2212-6.

35. Raz-Pasteur A, Gamliel-Lazarovich A, Coleman R, Keidar S. Eplerenone reduced lesion size in early but not advanced atherosclerosis in apolipoprotein e-deficient mice. J Cardiovasc Pharmacol. 2012;60(6):508-12.

\section{Publisher's Note}

Springer Nature remains neutral with regard to jurisdictional claims in published maps and institutional affiliations.
Ready to submit your research? Choose BMC and benefit from:

- fast, convenient online submission

- thorough peer review by experienced researchers in your field

- rapid publication on acceptance

- support for research data, including large and complex data types

- gold Open Access which fosters wider collaboration and increased citations

- maximum visibility for your research: over $100 \mathrm{M}$ website views per year

At $\mathrm{BMC}$, research is always in progress.

Learn more biomedcentral.com/submissions 